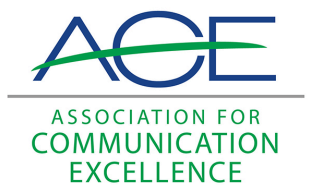

Journal of Applied Communications

\title{
Using Mass Communication Theory; Cognitive Switching: A Behavioral Trace of Human Information Processing for Television Newscasts; Attitudes of Scientists and Journalists Toward Media Coverage of Science News
}

Larry Meiller

William Tedrick

Follow this and additional works at: https://newprairiepress.org/jac (c) (1) (2)(2)

This work is licensed under a Creative Commons Attribution-Noncommercial-Share Alike 4.0 License.

\section{Recommended Citation}

Meiller, Larry and Tedrick, William (1979) "Using Mass Communication Theory; Cognitive Switching: A Behavioral Trace of Human Information Processing for Television Newscasts; Attitudes of Scientists and Journalists Toward Media Coverage of Science News," Journal of Applied Communications: Vol. 62: Iss. 4. https://doi.org/10.4148/1051-0834.1886

This Review is brought to you for free and open access by New Prairie Press. It has been accepted for inclusion in Journal of Applied Communications by an authorized administrator of New Prairie Press. For more information, please contact cads@k-state.edu. 
Using Mass Communication Theory; Cognitive Switching: A Behavioral Trace of Human Information Processing for Television Newscasts; Attitudes of Scientists and Journalists Toward Media Coverage of Science News

\section{Abstract}

Reviews of Using Mass Communication Theory, by M.E. McCombs and L.B. Becker; "Cognitive Switching: A Behavioral Trace of Human Information Processing for Television Newscasts," by Thomas A. McCain and Mark G. Ross; "Attitudes of Scientists and Journalists Toward Media Coverage of Science News," by Michael Ryan. 


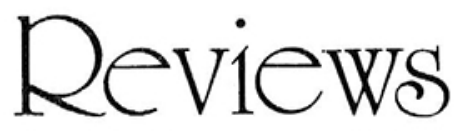

Reviews are prepared by Larry Meiller, John Fett and others in the Department of Agricultural Journalism, University of Wisconsin-Madison.

Using Mass Communication Theory, M.E. McCombs and L.B. Becker. Englewood Cliffs, N.J.: Prentice-Hall, 1979.

This book is the second in a series from Prentice-Hall dealing with perspectives in mass communication. It provides an overview of available information relating to the interaction of mass communication and society. The book is based on empirical research by social scientists and examines the many barriers to communication from the journalist's point of view.

The first chapter discusses the message and how the contents of the message relate to the experiences of the intended audience. The rest of the book looks at a number of barriers to communication. For example, the authors discuss differences in message perception, language as a barrier to message reception and the influence of the communicators' characteristics on the messages they generate. Also examined are problems relating to the influence of organizational settings on the nature of the message; legal, cultural and economic restraints on communication performance; and mass communication effects. The book concludes with a synthesis of the areas covered.

ACE members should consider purchasing this worthwhile book.

Larry Meiller, University of Wisconsin 
"Cognitive Switching: A Behavioral Trace of Human Information Processing for Television Newscasts." Thomas A. McCain and Mark G. Ross. Journal of Human Communications. Vol. 5. No. 2, winter 1979.

The next time you present a television broadcast or develop a film you may want to give some thought to the concept identified as "cognitive switching" according to McCain and Ross.

Their work assumes that our thinking process is limited by time and space. Time is defined as how long we can recall information, and space is the amount of information we can handle in our thinking processes. They propose that we process information serially or discreetly, thus we can handle only so much information at a given time. Fortunately or unfortunately, depending upon your point of view. the authors say we humans possess a single channel information processing system.

If one buys these assumptions and propositions. McCain and Ross say, it follows that cognitive switching is the process by which people organize and use incoming information. They suggest that "switching" or information processing stops when we people: agree, disagree, think and question incoming information through the single channel system we possess. The researchers further propose that people exhibit similar cognitive switching behaviors in similar information-processing situations. Their study was designed to test three hypotheses:

1. Subjects who cognitively switch for specified-state functions (agree, disagree, think, question) will exhibit similar distributions of switching behavior as subjects with non-specified-state functions, while viewing television newscasts.

2. Subject-generated reasons for cognitively switching will be positively related to the four state functions of agreeing, disagreeing, thinking and questioning.

3. Subjects' cognitive switching distributions will be similar over time from newscast to newscast. 
They tested hypothesis 1 and 2 by using a computer assisted system designed to record each time the subject entered a thinking process switching mode. One half of the group was told to indicate when they made a switch for the specific-state functions of agreeing, disagreeing, thinking and questioning by activating one of four buttons for each function. The other half of the group was instructed to use only one button to indicate a switch without knowing the specific reason. Each group viewed five different videotaped recordings of the "CBS Evening News" with Walter Cronkite.

Through statistical testing, they concluded that subjects who know in advance of the switching state functions and those who are not knowledgeable of the process did exhibit similar switching behavior in the same communications situation. But they found that the subjects, who did not show a strong relationship of the number of switching behaviors recorded, varied significantly between telecasts viewed by the two groups.

The second hypothesis received strong support. It tested the assumption that the non-specified group would report switching for the same reasons (agree, disagree, think and question) as the informed group. McCain and Ross found that 84 percent of the reasons for switching given by the non-specified group were accounted for by thinking, agreeing, disagreeing and questioning.

Perhaps the practitioner should think about the way people think when developing messages for human processing. The amount of times we require a person to switch to agree, disagree, think and question may affect how fast we should present information. It also might affect how much information we can expect to be processed in a given time span. Most of us already knew that, but perhaps now we have a different understanding of why there is a relationship.

William Tedrick

Texas A \& M University 
"Attitudes of Scientists and Journalists Toward Media Coverage of Science News,"' Michael Ryan. Journalism Quarterly, Vol. 56, No. 1, spring 1979.

Communication scholars have shown considerable interest in how different groups-scientists, science writers, editors and the general public-view issues related to science news coverage. This research examined the extent of agreement between two groupsscience writers and scientists-about major issues in science coverage. Ryan also looked at how much of a difference each group perceived between their views and those of the other group. He also studied the extent to which they accurately predicted the views of individuals in the other group.

Ryan used a coorientation model to measure the attitudes of the people in each group toward science news coverage and its problems. Members of each group also were asked to predict responses of members of the other group. Eleven-page questionnaires were mailed to science writers listed in the 1976 edition of Editor and Publisher International Year Book and to a systematic sample of scientists whose studies were reported in the press. Some 122 of 198 writers and 110 of 140 scientists responded to the survey.

The results show the attitudes of the two groups toward science news coverage are similar. Both agreed headlines on science stories often are misleading, that scientists do not understand the problems reporters face in writing for the public and that scientists should cooperate with reporters even if those reporters appear inadequately trained in science.

But definite disagreements exist. For example, science writers disagreed with the notion of having their stories read before publication, by the scientists they quoted. Science writers also said reporters should not write the headlines for science articles and that they should not completely rely on scientists to point out the most important contribution of the scientist's research. Additionally, they said a scientist should release scientific research results before the information has appeared in a scientific journal, that a science writhttps:/ newprairiepress.org/jac/vol62/iss4/9 
er should attempt to interpret scientists' conclusions, and that science writers do not sensationalize news.

Scientists opposed writers on each of those issues. Ryan notes it is in these areas of disagreement that serious barriers to effective science news communication are most likely to occur.

While there were disagreements over the items listed above, both groups accurately predicted that those differences would exist. However, each group perceived a larger gap than actually existed. Nevertheless, each group at least perceived the nature of the disagreement accurately.

Larry Meiller, University of Wisconsin 